This is the final peer-reviewed accepted manuscript of:

Andrea Fiorani, Irkham, Giovanni Valenti, Francesco Paolucci, and Yasuaki Einaga Electrogenerated Chemiluminescence with Peroxydisulfate as a Coreactant Using Boron Doped Diamond Electrodes

Analytical Chemistry 201890 (21), 12959-12963

The final published version is available online at: https://doi.org/10.1021/acs.analchem.8b03622

Rights / License:

The terms and conditions for the reuse of this version of the manuscript are specified in the publishing policy. For all terms of use and more information see the publisher's website.

This item was downloaded from IRIS Università di Bologna (https://cris.unibo.it/)

When citing, please refer to the published version. 


\title{
Electrogenerated Chemiluminescence with Peroxydisulfate as a Coreactant Using Boron Doped Diamond Electrodes
}

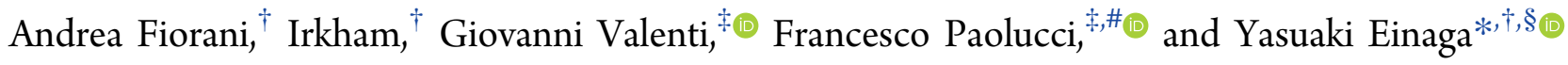 \\ ${ }^{\dagger}$ Department of Chemistry, Keio University, 3-14-1 Hiyoshi, Yokohama 223-8522, Japan \\ ${ }^{\ddagger}$ Department of Chemistry “G. Ciamician”, University of Bologna, Via Selmi, 2, 40126 Bologna, Italy \\ §JST-ACCEL, 3-14-1 Hiyoshi, Yokohama 223-8522, Japan \\ \#ICMATE-CNR Bologna Associate Unit, University of Bologna, 40126, Bologna, Italy
}

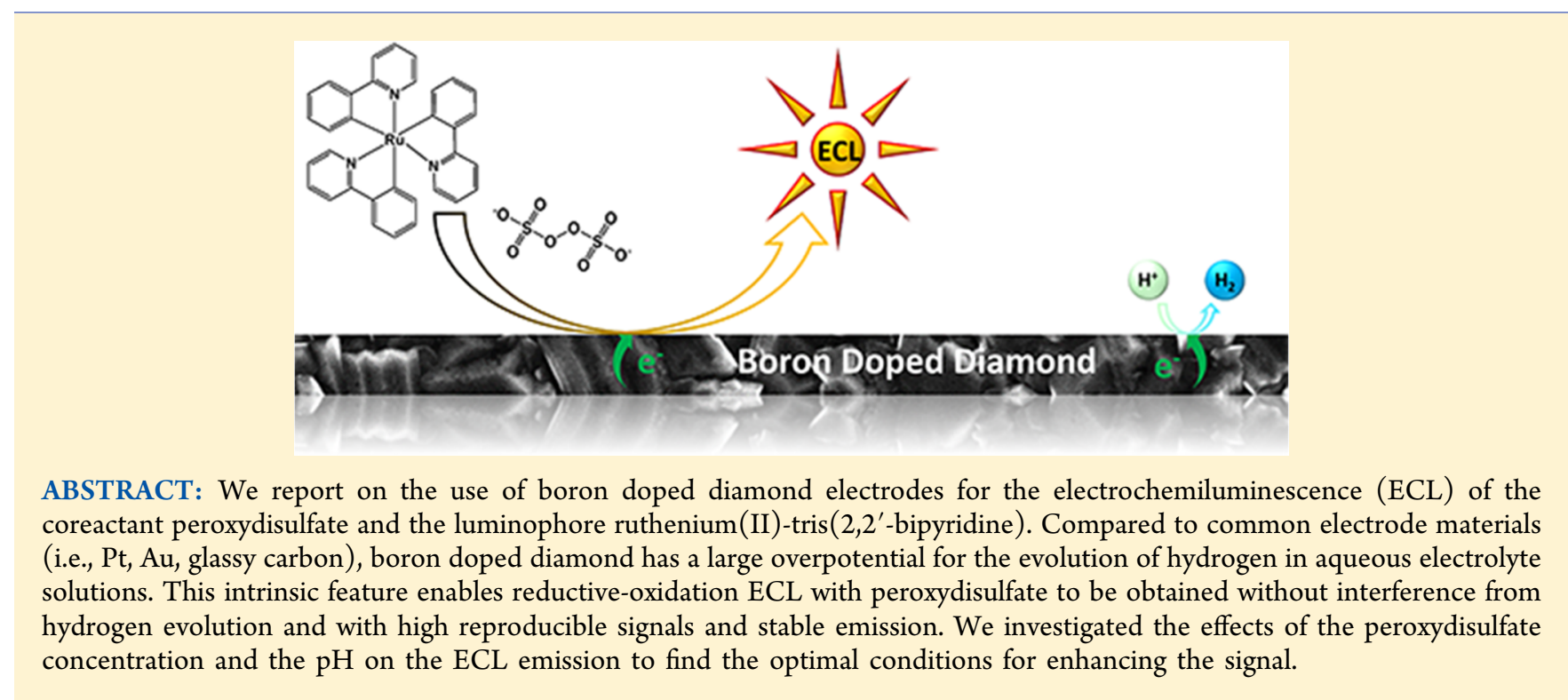

$\mathrm{E}$ lectrogenerated chemiluminescence (ECL) is a complex phenomenon involving light emission triggered by electrochemical reactions at an electrode surface. Despite the emission being generated from an excited state by a homogeneous electron transfer in solution, ECL is highly dependent on the electrode material, since this may have a large effect on the heterogeneous electron transfer that ignites ECL. ${ }^{2}$ The combination of electrode material and solvent is also extremely important, fixing the available potential window.

Nowadays, aqueous solutions are prominent in analytical ECL applications, ${ }^{3-5}$ and thanks to the optimal signal-to-noise ratio, ECL is a leading technique in bioanalysis, also in very complex matrixes such as urine and serum. ${ }^{6-8}$ On the other hand, organic solvents retain a useful application in luminophores characterization, ${ }^{9-13}$ emitting devices, ${ }^{14-18}$ and mixed annihilation. ${ }^{19,20}$ However, water oxidation and hydrogen evolution hampers the possibilities of ECL. This drawback has been overcome by the use of a coreactant, a sacrificial molecule that allows the generation of ECL within the water potential window. This dependency was investigated to a great extent for many ECL coreactant/electrode material systems ${ }^{2}$ and mainly for the oxidative-reduction ECL mechanism of $\mathrm{Ru}(\mathrm{bpy})_{3}{ }^{2+} /$ tri- $n$-propylamine. $^{21,22}$

For example, ECL for the $\mathrm{Ru}(\mathrm{bpy})_{3}{ }^{2+} /$ tri- $n$-propylamine system has oxidation potentials of 1.27 and $1.12 \mathrm{~V}$ (vs NHE), respectively, which are comparable or lower than the potential for water oxidation, $1.23 \mathrm{~V}$ (vs NHE).

On the other hand, ECL working with a cathodic current by the reductive-oxidation coreactant mechanism can be easily hampered by hydrogen evolution. ${ }^{23}$ In fact this approach is used mainly in organic solvents, ${ }^{24,25}$ although coreactant ECL has been reported for water solutions with carbon paste electrodes and glassy carbon electrodes, for peroxydisulfate $^{26-28}$ and hydrogen peroxide. ${ }^{29}$ In this context, the electrode material can play a crucial role by shifting the hydrogen evolution to a higher potential, while retaining the reduction potentials for the ECL reactants. ${ }^{2,30}$

Boron doped diamond electrodes (BDD) have a wider potential window in water compared to common electrode materials, with a high overpotential for hydrogen evolution, ${ }^{31,32}$ thus are highly suited to reductive-oxidation ECL in water. Moreover, the properties of BDD electrodes are tunable 
by the amount of $\mathrm{sp}^{2}$ carbon $^{33,34}$ and various surface functionalizations are easily accessible. ${ }^{35-37}$ However, nowadays, ECL applications of the reductive-oxidation of peroxydisulfate are performed at GC or carbon based electro$\mathrm{des}^{38-44}$ that limit the sensitivity of this ECL system.

Here, we report on the electrogenerated chemiluminescence of the $\mathrm{Ru}(\mathrm{bpy})_{3}{ }^{2+} /$ peroxydisulfate system using boron doped diamond electrodes. We examine a wide range of peroxydisulfate concentrations and the effect of the $\mathrm{pH}$ value.

\section{EXPERIMENTAL SECTION}

Materials. $\mathrm{Ru}(\text { bpy })_{3} \mathrm{Cl}_{2} \cdot 6 \mathrm{H}_{2} \mathrm{O}, \mathrm{NaClO}_{4}, \mathrm{Na}_{2} \mathrm{~S}_{2} \mathrm{O}_{8}$, $\mathrm{KH}_{2} \mathrm{PO}_{4}$, and $\mathrm{Na}_{2} \mathrm{HPO}_{4}$ were purchased from Wako Pure Chemical (JP) and used without further purification. A phosphate buffer (PB) was prepared at $\mathrm{pH} 6.8$ using $\mathrm{KH}_{2} \mathrm{PO}_{4}$ and $\mathrm{Na}_{2} \mathrm{HPO}_{4}$ only. Pure double distilled water (ddw), conductivity $<18 \mathrm{M} \Omega$, was obtained from a SimplyLab water system (DIRECT-Q3 UV, Millipore).

Preparation of BDD. The BDD films were deposited on a silicon (111) wafer using a microwave plasma-assisted chemical vapor deposition (MPCVD) system (CORNES Technologies/ASTeX-5400). Trimethoxyborane and acetone were used as the boron and carbon sources, respectively, with an atomic ratio of $B / C=1 \%\left(B \approx 2 \times 10^{21} / \mathrm{cm}^{3}\right)$. The surface morphology of the BDD was examined using a field emission scanning electron microscope (FESEM, JEOL JSM-7600F). Raman spectra were recorded with an Acton SP2500 (Princeton Instruments) with an excitation wavelength of $532 \mathrm{~nm}$ from a green laser diode at ambient temperature (Figure S1).

Electrochemical Measurements. All the ECL measurements were conducted with a conventional three-electrode system in a PTFE cell $\left(2.5 \mathrm{~cm}^{3}\right)$ with a $1 \% \mathrm{BDD}$, a Pt or glassy carbon (GC) working electrodes $\left(0.635 \mathrm{~cm}^{2}\right)$, counter platinum spiral, and $\mathrm{Ag} / \mathrm{AgCl}$ (saturated $\mathrm{KCl}$ ) reference electrode (all potentials throughout the text are referred to this electrode). The electrodes were connected to an Autolab PGSTAT302N (Metrohom).

The ECL signal was measured with a photomultiplier tube (PMT, Hamamatsu R928) placed at a fixed height from the electrochemical cell, inside a dark box. A high voltage power supply socket assembly with a transimpedance amplifier (Hamamatsu C6271) was used to supply $500 \mathrm{~V}$ to the PMT, using an external trigger connection to the Autolab DAC module. Light/current/voltage curves were recorded by collecting the amplified PMT output signal with the ADC module of the Autolab. ECL spectra were collected by a SEC2000 Spectra system UV-visible spectrophotometer (ALS Co., JP), by means of an optical fiber on top of the electrochemical cell.

The BDD electrode was cleaned by sonication in isopropanol for $5 \mathrm{~min}$, rinsed in $\mathrm{ddw}$, and dried in a stream of nitrogen. Prior to each ECL measurement, the BDD surface was pretreated electrochemically to guarantee reproducibility, by performing 10 voltammetric cycles between -2.0 and $2.0 \mathrm{~V}$ followed by 10 cycles between 0 and $-2.0 \mathrm{~V}$ in a $0.1 \mathrm{M}$ $\mathrm{NaClO}_{4}$ solution at a scan rate $0.3 \mathrm{~V} / \mathrm{s}$. The GC (Tokai Carbon, JP) and Pt (Nilaco Co., JP) electrodes were cleaned with $0.5 \mu \mathrm{m}$ alumina powder on cloth tape, then sonicated in $\mathrm{ddw}$ for $5 \mathrm{~min}$, rinsed in $\mathrm{ddw}$, and dried in a nitrogen stream.

\section{RESULTS AND DISCUSSION}

First, we investigated the ECL of $\mathrm{Ru}(\mathrm{bpy}){ }_{3}{ }^{2+} /$ peroxydisulfate at a BDD electrode by cyclic voltammetry and we compared this with the results obtained using $\mathrm{Pt}$ and GC electrodes (Figure 1). However, there were no ECL signals with the $\mathrm{Pt}$
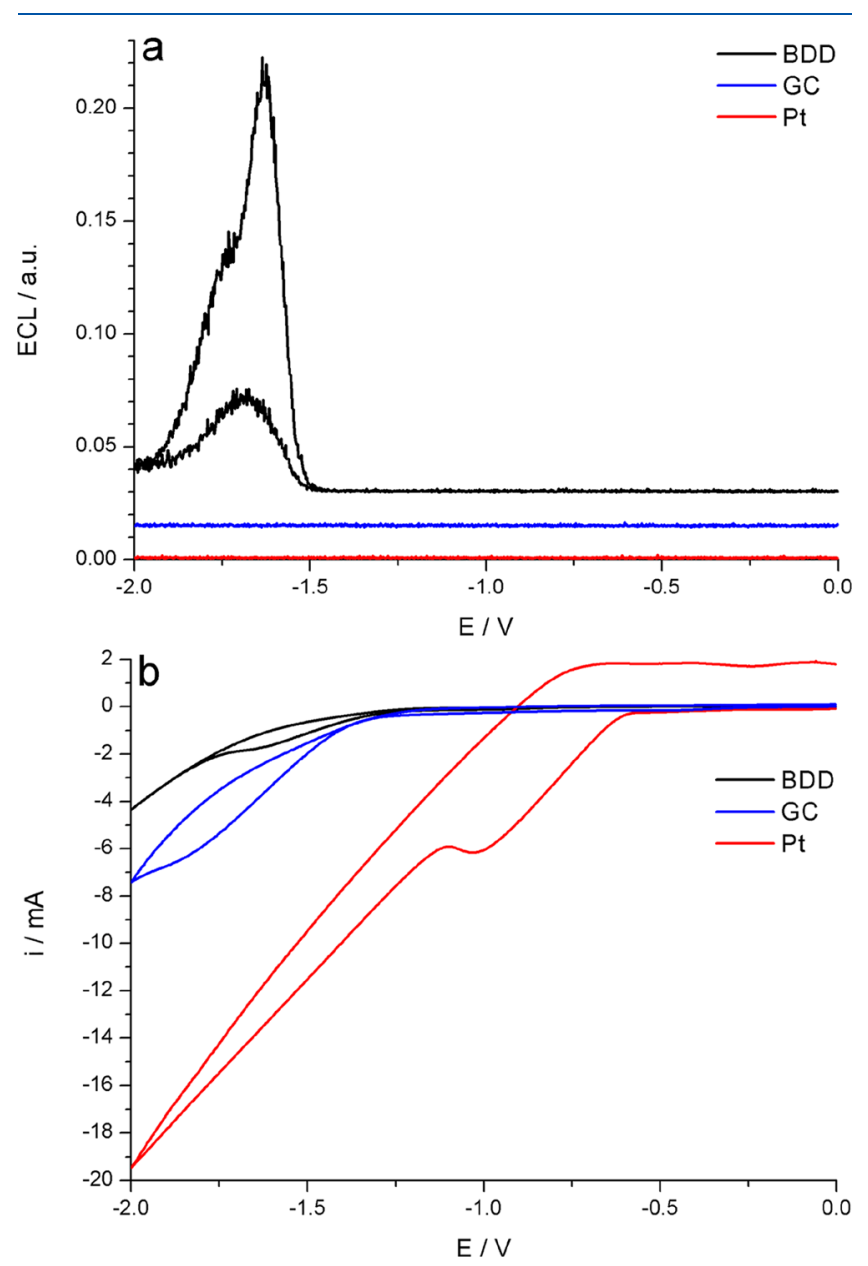

Figure 1. Comparison of ECL (a) and CV (b) with BDD (black), GC (blue), and $\mathrm{Pt}$ (red) electrodes for $10 \mu \mathrm{M} \mathrm{Ru}(\mathrm{bpy})_{3}{ }^{2+}$ and $100 \mu \mathrm{M}$ $\mathrm{S}_{2} \mathrm{O}_{8}{ }^{2-}$ in $200 \mathrm{mM}$ PB. The scan rate is $100 \mathrm{mV} / \mathrm{s}$ and the $\mathrm{pH}$ 6.8. In part a, the curves are shifted for clarity.

and GC electrodes, though there was detectable ECL emission for $\mathrm{Ru}(\mathrm{bpy})_{3}{ }^{2+} /$ peroxydisulfate with the GC electrode when the concentration was 5 times higher (Figure S2). In contrast, the ECL signal from the BDD electrode was high. The rate of hydrogen evolution, which is related to the cathodic current (BDD < GC « Pt), adversely affects the ECL emission, preventing light detection, and hindering the reduction of $\mathrm{Ru}(\mathrm{bpy}){ }_{3}{ }^{2+}$ and peroxydisulfate in favor of proton reduction. The higher overpotential for proton reduction at BDD, compared to GC and $\mathrm{Pt}$, makes diamond electrodes far superior for reductive-oxidation ECL in aqueous solutions.

The ECL signal starts at $-1.47 \mathrm{~V}$ corresponding to $\mathrm{Ru}(\mathrm{bpy})_{3}{ }^{2+} / \mathrm{Ru}(\mathrm{bpy})_{3}{ }^{+}\left(E^{0}=-1.46 \mathrm{~V}\right)$, with a steep rise at $-1.5 \mathrm{~V}$ and a maximum at $-1.6 \mathrm{~V}$. The ECL with the GC electrode shows similar potentials; however, a higher concentration of $\mathrm{Ru}(\mathrm{bpy})_{3}{ }^{2+}$ /peroxydisulfate was needed (Figure S2), similar to that used by Choi and Bard where $\mathrm{Ru}(\mathrm{bpy}){ }_{3}{ }^{2+}$ was in the millimolar concentration range. ${ }^{29}$ The BDD electrode has high ECL stability with repetitive cycling 
(Figure S3), even though a decrease in the emission is observed after the first cycle, likely due to surface modification after the potential scan, ${ }^{31,32,37}$ and commonly observed for the ECL emission. ${ }^{21,30}$

The ECL with the BDD electrode features two emission peaks at different potentials. In the ECL plot, $\mathrm{Ru}(\mathrm{bpy})_{3}{ }^{2+*}$ is identified as the emitting species, with a maximum at $610 \mathrm{~nm}$ for $-1.6 \mathrm{~V}$, together with a second peak at $630 \mathrm{~nm}$ at a potential of $-1.7 \mathrm{~V}$ (Figure 2 and Figure S4).

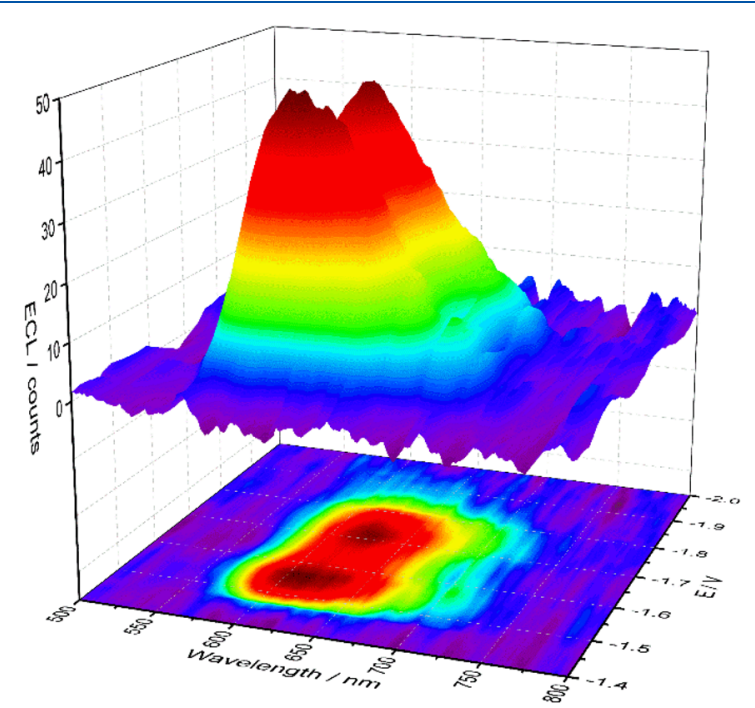

Figure 2. 3D surface plot of ECL spectrum with a BDD electrode as a function of applied potential. The solution is $10 \mu \mathrm{M} \mathrm{Ru}(\mathrm{bpy})_{3}{ }^{2+}$ and $100 \mu \mathrm{M} \mathrm{S}_{2} \mathrm{O}_{8}^{2-}$ in $200 \mathrm{mM}$ PB. The scan rate is $100 \mathrm{mV} / \mathrm{s}$ and the $\mathrm{pH}$ 6.8. Integration time for the spectrum: $200 \mathrm{~ms}$.

The ECL underlying the first peak is described by reactions 1-8 in Scheme 1, the mechanism of reductive-oxidation ECL for $\mathrm{Ru}(\mathrm{bpy})_{3}{ }^{2+} /$ peroxydisulfate. $^{23,30,45}$

\section{Scheme 1}

$$
\begin{aligned}
& \mathrm{S}_{2} \mathrm{O}_{8}^{2-}+\mathrm{e}^{-} \rightarrow \mathrm{S}_{2} \mathrm{O}_{8}{ }^{\bullet-} \\
& {\left[\mathrm{Ru}(\text { bpy })_{3}\right]^{2+}+\mathrm{e}^{-} \rightarrow\left[\mathrm{Ru}(\text { bpy })_{3}\right]^{+}} \\
& {\left[\mathrm{Ru}(\text { bpy })_{3}\right]^{+}+\mathrm{S}_{2} \mathrm{O}_{8}{ }^{2-} \rightarrow\left[\mathrm{Ru}(\text { bpy })_{3}\right]^{2+}+\mathrm{S}_{2} \mathrm{O}_{8}{ }^{\bullet-}} \\
& \mathrm{S}_{2} \mathrm{O}_{8}^{\bullet \bullet-} \rightarrow \mathrm{SO}_{4}{ }^{2-}+\mathrm{SO}_{4}^{\bullet-} \\
& {\left[\mathrm{Ru}(\text { bpy })_{3}\right]^{+}+\mathrm{SO}_{4}^{\bullet-} \rightarrow\left[\mathrm{Ru}(\text { bpy })_{3}\right]^{2+*}+\mathrm{SO}_{4}{ }^{2-}} \\
& {\left[\mathrm{Ru}(\text { bpy })_{3}\right]^{2+}+\mathrm{SO}_{4}{ }^{\bullet-} \rightarrow\left[\mathrm{Ru}(\text { bpy })_{3}\right]^{3+}+\mathrm{SO}_{4}{ }^{2-}} \\
& {\left[\mathrm{Ru}(\text { bpy })_{3}\right]^{3+}+\left[\mathrm{Ru}(\text { bpy })_{3}\right]^{+} \rightarrow} \\
& \quad\left[\mathrm{Ru}(\text { bpy })_{3}\right]^{2+*}+\left[\mathrm{Ru}(\text { bpy })_{3}\right]^{2+} \\
& {\left[\mathrm{Ru}(\text { bpy })_{3}\right]^{2+*} \rightarrow\left[\mathrm{Ru}(\text { bpy })_{3}\right]^{2+}+h v}
\end{aligned}
$$

The second ECL peak, which is a shoulder on the main peak, is cautiously ascribed to emitting oxygen species generated by peroxydisulfate (Scheme 2, reactions 9-15). ${ }^{46}$ This ECL emission has previously been demonstrated for electrolysis in an aqueous solution of peroxydisulfate, where excited oxygen species such as ${ }^{1} \mathrm{O}_{2},{ }^{1}\left(\mathrm{O}_{2}\right)_{2}$, and ${ }^{3}\left(\mathrm{O}_{2}\right)_{2}$ were generated. ${ }^{2,47,48}$ The emission is quite broad, with a range of wavelengths from 500 to $700 \mathrm{~nm}$. In particular, a peak at 634 $\mathrm{nm}$ can be assigned to the chemiluminescent reaction $\left(\mathrm{O}_{2}\left({ }^{1} \Delta_{\mathrm{g}}\right)\right)_{2} \rightarrow\left(\mathrm{O}_{2}\left({ }^{3} \Sigma_{\mathrm{g}}-\right)\right)_{2},{ }^{49-52}$ which is very close and can be ascribed to the observed ECL peak of $630 \mathrm{~nm}$.
Scheme 2

$$
\begin{aligned}
& \mathrm{O}_{2}+\mathrm{H}_{3} \mathrm{O}^{+}+e^{-} \rightarrow \mathrm{HO}_{2}{ }^{\bullet}+\mathrm{H}_{2} \mathrm{O} \\
& \mathrm{O}_{2}+\mathrm{H}_{2} \mathrm{O}+e^{-} \rightarrow \mathrm{HO}_{2}{ }^{\bullet}+\mathrm{OH}^{-} \\
& \mathrm{O}_{2}+e^{-} \rightarrow \mathrm{O}_{2}{ }^{\bullet-} \\
& \mathrm{HO}_{2}{ }^{\bullet}+\mathrm{SO}_{4}{ }^{\bullet-} \rightarrow \mathrm{HSO}_{4}{ }^{-}+\mathrm{O}_{2}{ }^{*} \\
& \mathrm{O}_{2}{ }^{\bullet-}+\mathrm{S}_{2} \mathrm{O}_{8}{ }^{2-} \rightarrow \mathrm{O}_{2}{ }^{*}+\mathrm{SO}_{4}{ }^{\bullet-}+\mathrm{SO}_{4}{ }^{2-} \\
& \mathrm{O}_{2}{ }^{\bullet-}+\mathrm{SO}_{4}{ }^{--} \rightarrow \mathrm{O}_{2}{ }^{*}+\mathrm{SO}_{4}{ }^{2-} \\
& \mathrm{O}_{2}{ }^{*} \rightarrow \mathrm{O}_{2}+h v
\end{aligned}
$$

The ECL response as a function of the peroxydisulfate concentration was assessed in the range from $1 \mu \mathrm{M}$ to $100 \mathrm{mM}$ (Figure 3). A linear increase was found at low peroxydisulfate

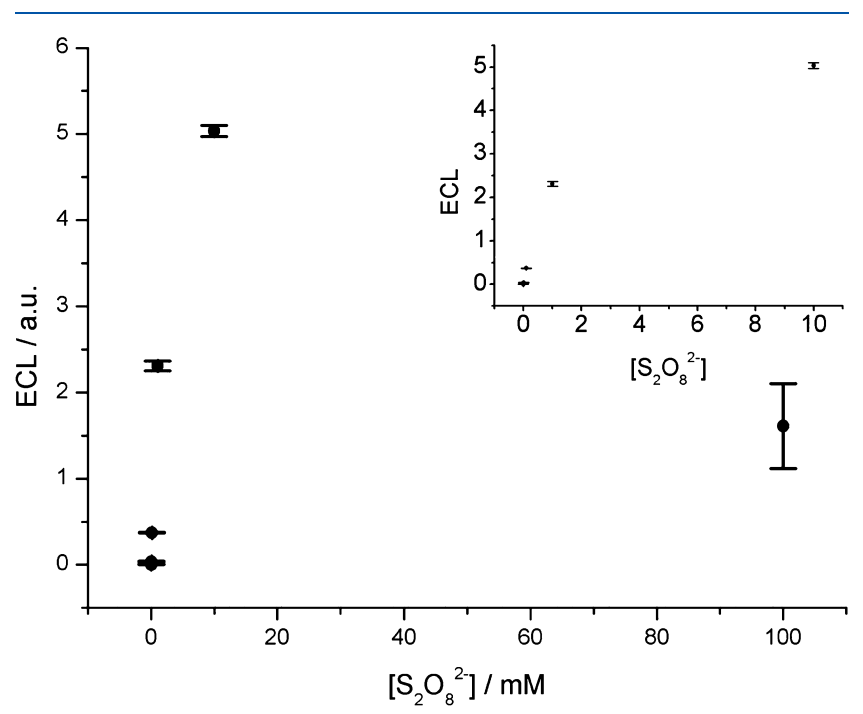

Figure 3. Integrated ECL emission with a $\mathrm{BDD}$ electrode as a function of $\mathrm{S}_{2} \mathrm{O}_{8}{ }^{2-}$ concentration, from $1 \mu \mathrm{M}$ to $100 \mathrm{mM}$, by cyclic voltammetry. Inset: magnification of ECL response from $1 \mu \mathrm{M}$ to 10 $\mathrm{mM}$. Solution, $10 \mu \mathrm{M} \mathrm{Ru}(\text { bpy })_{3}{ }^{2+}$ in $200 \mathrm{mM} \mathrm{PB}$; scan rate, $100 \mathrm{mV} /$ s; $\mathrm{pH}, 6.8$.

concentrations $(1-100 \mu \mathrm{M})$, resulting in LOD $=0.5 \mu \mathrm{M}$ and $\mathrm{LOQ}=1 \mu \mathrm{M}$ (Figure S5). The maximum emission occurs at $10 \mathrm{mM}$, while at $100 \mathrm{mM}$, the emission is much less.

This trend in ECL emission for peroxydisulfate has been observed previously, ${ }^{23,45}$ and it reflects the oxidative quenching of peroxydisulfate on the excited state of $\mathrm{Ru}(\mathrm{bpy})_{3}{ }^{2+}$ by reaction 16, with a quenching rate constant $\left(k_{\mathrm{q}}\right)$ and an electron transfer rate constant $\left(k_{\mathrm{et}}\right)$ within the excited-state ion pair $\left(\mathrm{Ru}(\text { bpy })_{3}{ }^{2+*} \mid \mathrm{S}_{2} \mathrm{O}_{8}{ }^{2-}\right)$ of $9.8 \times 10^{8} \mathrm{M}^{-1} \mathrm{~s}^{-1}$ and $4.2 \times 10^{8}$ $\mathrm{s}^{-1}$, respectively. ${ }^{53}$ Interestingly, we found new evidence for ECL emission for solutions with a $\mathrm{Ru}(\mathrm{bpy})_{3}{ }^{2+} /$ peroxydisulfate ratio down to $1 / 1000(10 \mu \mathrm{M} / 10 \mathrm{mM})$, while previous data from White et al. ${ }^{23}$ reported a value of $1 / 20$ and those from Yamazaki-Nishida et al. ${ }^{27}$ gave $1 / 200$. This increases the range of persulfate concentrations available that can be used profitably without interference by oxidative quenching, which will enable a wider range of $\mathrm{Ru}(\mathrm{bpy})_{3}{ }^{2+}$ detection.

$$
\begin{aligned}
& {\left[\mathrm{Ru}(\text { bpy })_{3}\right]^{2+*}+\mathrm{S}_{2} \mathrm{O}_{8}{ }^{2-}} \\
& \quad \rightarrow\left[\mathrm{Ru}(\mathrm{bpy})_{3}\right]^{3+}+\mathrm{SO}_{4}{ }^{2-}+\mathrm{SO}_{4}{ }^{\bullet-}
\end{aligned}
$$

We observed, not only changes in the ECL intensity with concentration but also in the relative intensities of the first and second peaks (Figure 4). While the first peak intensity 


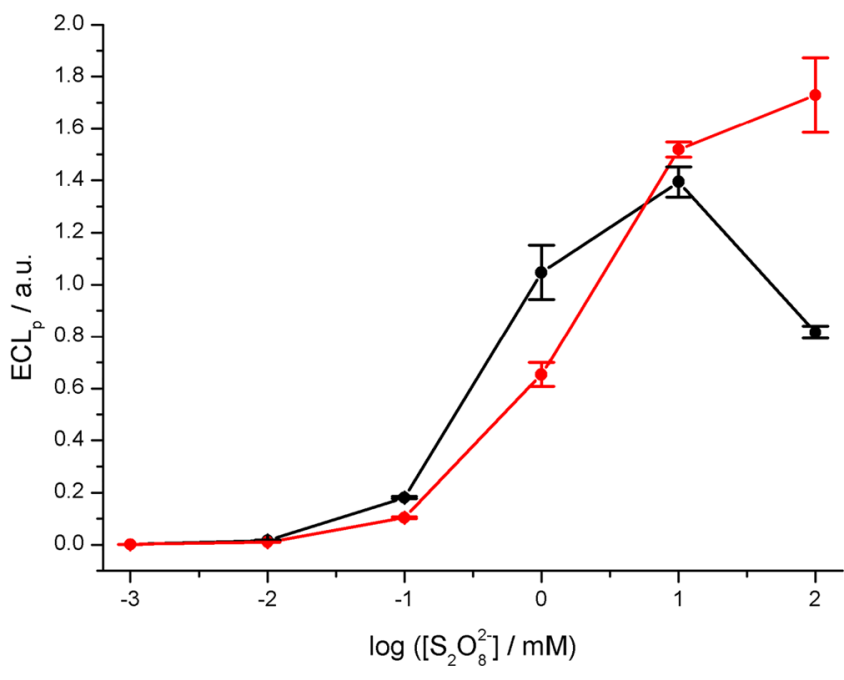

Figure 4. Comparison of ECL peak intensity for first (black) and second (red) peaks as a function of peroxydisulfate concentration. The scan rate is $100 \mathrm{mV} / \mathrm{s}$ and the $\mathrm{pH} 6.8$.

increases with concentration, through a maximum to a quenched emission, resembling the integrated ECL of Figure 3 , the second peak intensity increases with increasing peroxydisulfate concentration. These results support the assignment of first peak to ECL from $\mathrm{Ru}(\mathrm{bpy})_{3}{ }^{2+}$ /peroxydisulfate (Scheme 1) and the second peak to $\mathrm{O}_{2}$ /peroxydisulfate (Scheme 2).

Since the main drawback of reductive-oxidation processes in aqueous solutions is the evolution of hydrogen, we assessed the effect of $\mathrm{pH}$ on the ECL intensity by cyclic voltammetry, from $\mathrm{pH} 2$ to 9 (Figure 5). Even at higher concentrations of peroxydisulfate $(1 \mathrm{mM})$, the trend is similar (Figure S6).

A decrease in $\mathrm{pH}$ results in two distinctive effects, an increase in the ECL emission and a shift to negative potentials of the ECL peak (Figure 5b). The ECL decrease from $\mathrm{pH} 4$ to 9 can be ascribed to the quenching effect of hydroxyl ions on sulfate radical anions, with a rate constant of $6.5 \pm 1.0 \times 10^{7}$ $\mathrm{M}^{-1} \mathrm{~s}^{-1}$ (reaction 17). ${ }^{54}$

$$
\mathrm{SO}_{4}^{\bullet-}+\mathrm{OH}^{-} \rightarrow \mathrm{SO}_{4}^{2-}+\mathrm{OH}^{\bullet}
$$

Although the cathodic current for hydrogen evolution increases (Figure S7), this is not a limiting factor that hinders the ECL emission, at least until $\mathrm{pH} 4$, while for $\mathrm{pH} 3$ the ECL decreases and is completely turned off at $\mathrm{pH} 2$. However, this might be responsible for the shift in potential of the ECL peak to more negative values with decreasing $\mathrm{pH}$. The decrease in ECL due to hydrolysis of the peroxydisulfate is negligible, since the rate constants for the hydrogen ion catalyzed thermal decomposition of peroxydisulfate are very low at room temperature. ${ }^{55}$ A similar trend in ECL emission was previously observed, ${ }^{56}$ although by using ruthenium bipyrazine (Ru$\left.(\mathrm{bpz})_{3}{ }^{2+} / \mathrm{Ru}(\mathrm{bpz})_{3}{ }^{+} E^{0}=-0.77 \mathrm{~V}\right),{ }^{57}$ which can be protonated at low $\mathrm{pH}$, in that case decreasing the ECL emission.

\section{CONCLUSIONS}

Here, we report on the superiority of $\mathrm{BDD}$ as an electrode material for ECL from the coreactant peroxydisulfate in water. Nowadays, many ECL applications with peroxydisulfate are performed using GC or carbon based electrodes; however, BDD can effectively increase the ECL emission for peroxydisulfate, suppressing the hydrogen evolution and
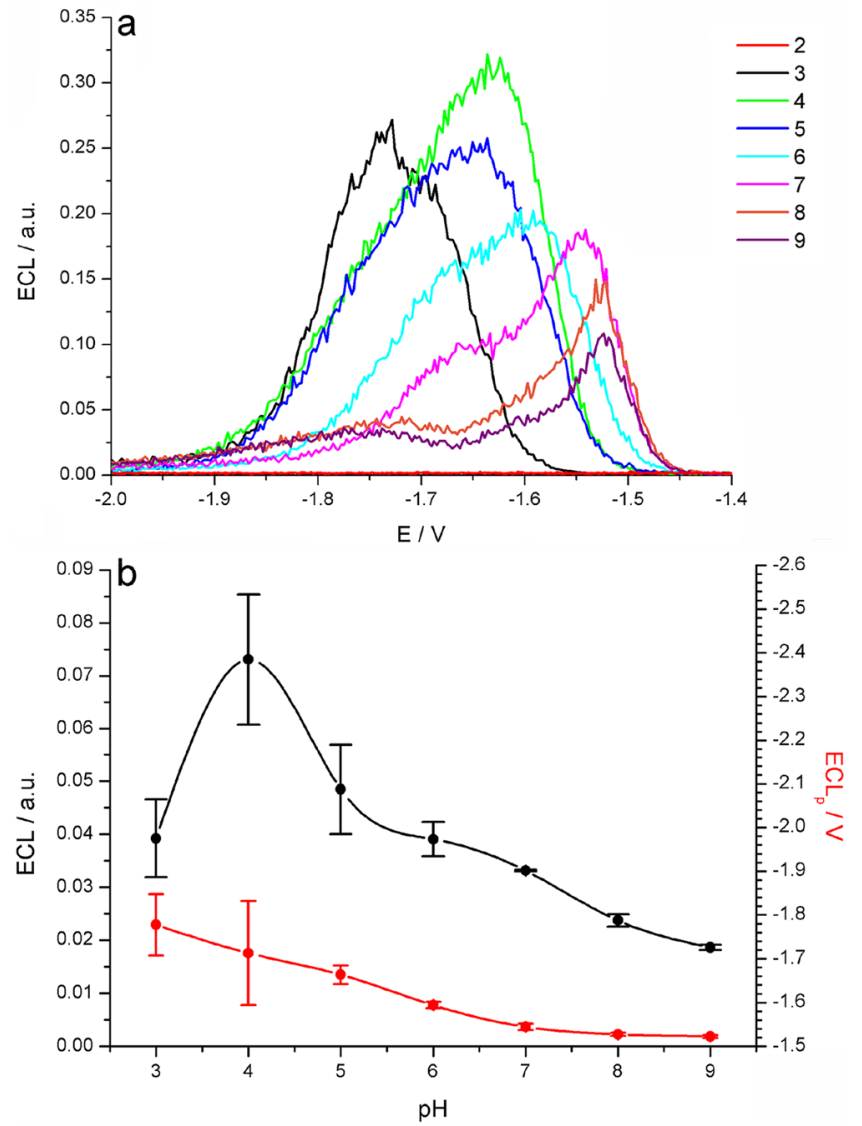

Figure 5. (a) ECL by CV for $10 \mu \mathrm{M} \mathrm{Ru}(\text { bpy })_{3}{ }^{2+}$ and $100 \mu \mathrm{M} \mathrm{S}_{2} \mathrm{O}_{8}{ }^{2-}$ in $200 \mathrm{mM} \mathrm{PB}$, for $\mathrm{pH} 2$ to 9 . The scan rate is $100 \mathrm{mV} / \mathrm{s}$. (b) Integrated ECL (black) and ECL peak potential (red) as functions of $\mathrm{pH}$.

increasing the stability, leading to higher sensitivity and lower detection limits, which cannot be reached using GC electrodes. ECL can be performed over a wide range of peroxydisulfate concentrations and $\mathrm{pH}$ values, thus meeting the experimental requirements of many applications. The reported results, besides contributing to a better understanding of the mechanisms operating in the generation of ECL, also pave the way for the development of highly efficient ECL for ultrasensitive bioanalysis.

\section{ASSOCIATED CONTENT}

\section{Supporting Information}

The Supporting Information is available free of charge on the ACS Publications website at DOI: 10.1021/acs.analchem. 8 b03622.

BDD Raman spectra and SEM micrographs, ECL at GC, ECL spectra at selected potentials, peroxydisulfate LOD and $\mathrm{LOQ}$ and ECL and cathodic currents for $\mathrm{pH}$ variation $(\mathrm{PDF})$ 
Notes

The authors declare no competing financial interest.

\section{ACKNOWLEDGMENTS}

G.V. and F.P. thank the University of Bologna, Italian Ministero dell'Istruzione, Università e Ricerca (MIUR-Project) and FARB, Fondazione Cassa di Risparmio in Bologna.

\section{REFERENCES}

(1) Fiorani, A.; Valenti, G.; Iurlo, M.; Marcaccio, M.; Paolucci, F. Curr. Opin. Electrochem. 2018, 8, 31-38.

(2) Valenti, G.; Fiorani, A.; Li, H.; Sojic, N.; Paolucci, F. ChemElectroChem 2016, 3, 1990-1997.

(3) Hesari, M.; Ding, Z. J. Electrochem. Soc. 2016, 163, H3116$\mathrm{H} 3131$.

(4) Richter, M. M. Chem. Rev. 2004, 104, 3003-3036.

(5) Miao, W. Chem. Rev. 2008, 108, 2506-2553.

(6) Valenti, G.; Rampazzo, E.; Biavardi, E.; Villani, E.; Fracasso, G.; Marcaccio, M.; Bertani, F.; Ramarli, D.; Dalcanale, E.; Paolucci, F.; Prodi, L. Faraday Discuss. 2015, 185, 299-309.

(7) Li, L.; Chen, Y.; Zhu, J.-J. Anal. Chem. 2017, 89, 358-371.

(8) Liu, Z.; Qi, W.; Xu, G. Chem. Soc. Rev. 2015, 44, 3117-3142.

(9) Valenti, G.; Fiorani, A.; Di Motta, S.; Bergamini, G.; Gingras, M.; Ceroni, P.; Negri, F.; Paolucci, F.; Marcaccio, M. Chem. - Eur. J. 2015, 21, 2936-2947.

(10) Hsu, C. W.; Longhi, E.; Sinn, S.; Hawes, C. S.; Young, D. C.; Kruger, P. E.; De Cola, L. Chem. - Asian J. 2017, 12, 1649-1658.

(11) Hesari, M.; Barbon, S. M.; Mendes, R. B.; Staroverov, V. N.; Ding, Z.; Gilroy, J. B. J. Phys. Chem. C 2018, 122, 1258-1266.

(12) Kapturkiewicz, A. Anal. Bioanal. Chem. 2016, 408, 7013-7033.

(13) Li, H.; Voci, S.; Wallabregue, A.; Adam, C.; Labrador, G. M.; Duwald, R.; Delgado, I. H.; Pascal, S.; Bosson, J.; Lacour, J.; Bouffier, L.; Sojic, N. ChemElectroChem 2017, 4, 1750-1756.

(14) Horiuchi, T.; Niwa, O.; Hatakenaka, N. Nature 1998, 394, $659-661$.

(15) Nobeshima, T.; Nakakomi, M.; Nakamura, K.; Kobayashi, N. Adv. Opt. Mater. 2013, 1, 144-149.

(16) Tsuneyasu, S.; Ichihara, K.; Nakamura, K.; Kobayashi, N. Phys. Chem. Chem. Phys. 2016, 18, 16317-16324.

(17) Tsuneyasu, S.; Ichikawa, T.; Nakamura, K.; Kobayashi, N. ChemElectroChem 2017, 4, 1731-1735.

(18) Kong, S. H.; Lee, J. I.; Kim, S.; Kang, M. S. ACS Photonics 2018, $5,267-277$

(19) Kerr, E.; Doeven, E. H.; Barbante, G. J.; Hogan, C. F.; Bower, D. J.; Donnelly, P. S.; Connell, T. U.; Francis, P. S. Chem. Sci. 2015, 6, $472-479$.

(20) Kerr, E.; Doeven, E. H.; Barbante, G. J.; Hogan, C. F.; Hayne, D. J.; Donnelly, P. S.; Francis, P. S. Chem. Sci. 2016, 7, 5271-5279.

(21) Zu, Y.; Bard, A. J. Anal. Chem. 2000, 72, 3223-3232.

(22) Zu, Y.; Bard, A. J. Anal. Chem. 2001, 73, 3960-3964.

(23) White, H. S.; Bard, A. J. J. Am. Chem. Soc. 1982, 104, 68916895.

(24) Valenti, G.; Bruno, C.; Rapino, S.; Fiorani, A.; Jackson, E. A.; Scott, L. T.; Paolucci, F.; Marcaccio, M. J. Phys. Chem. C 2010, 114, 19467-19472.

(25) Kudruk, S.; Villani, E.; Polo, F.; Lamping, S.; Körsgen, M.; Arlinghaus, H. F.; Paolucci, F.; Ravoo, B. J.; Valenti, G.; Rizzo, F. Chem. Commun. 2018, 54, 4999-5002.

(26) Yao, W.; Wang, L.; Wang, H.; Zhang, X. Electrochim. Acta 2008, 54, 733-737.

(27) Yamazaki-Nishida, S.; Harima, Y.; Yamashita, K. J. Electroanal. Chem. Interfacial Electrochem. 1990, 283, 455-458.

(28) Yamashita, K.; Yamazaki-Nishida, S.; Harima, Y.; Segawa, A. Anal. Chem. 1991, 63, 872-876.

(29) Choi, J.-P.; Bard, A. J. Anal. Chim. Acta 2005, 541, 141-148. (30) Villani, E.; Valenti, G.; Marcaccio, M.; Mattarozzi, L.; Barison, S.; Garoli, D.; Cattarin, S.; Paolucci, F. Electrochim. Acta 2018, 277, $168-175$.
(31) Einaga, Y. J. Appl. Electrochem. 2010, 40, 1807-1816.

(32) Cobb, S. J.; Ayres, Z. J.; Macpherson, J. V. Annu. Rev. Anal. Chem. 2018, 11, 463-484.

(33) Watanabe, T.; Honda, Y.; Kanda, K.; Einaga, Y. Phys. Status Solidi A 2014, 211, 2709-2717.

(34) Ayres, Z. J.; Newland, J. C.; Newton, M. E.; Mandal, S.; Williams, O. A.; Macpherson, J. V. Carbon 2017, 121, 434-442.

(35) Yamamoto, T.; Akahori, M.; Natsui, K.; Saitoh, T.; Einaga, Y. Carbon 2018, 130, 350-354.

(36) Ayres, Z. J.; Borrill, A. J.; Newland, J. C.; Newton, M. E.; Macpherson, J. V. Anal. Chem. 2016, 88, 974-980.

(37) McCreery, R. L. Chem. Rev. 2008, 108, 2646-2687.

(38) Russell, R.; Stewart, A. J.; Dennany, L. Anal. Bioanal. Chem. 2016, 408, 7129-7136.

(39) Cao, J.-T.; Liu, F.-R.; Hou, F.; Peng, J.; Ren, S.-W.; Liu, Y.-M. Analyst 2018, 143, 3702.

(40) Tian, K.; Nie, F.; Luo, K.; Zheng, X.; Zheng, J. J. Electroanal. Chem. 2017, 801, 162-170.

(41) Lei, Y.-M.; Wen, R.-X.; Zhou, J.; Chai, Y.-Q.; Yuan, R.; Zhuo, Y. Anal. Chem. 2018, 90, 6851-6858.

(42) Wu, F.; Feng, Y.; Chi, Y. J. Electroanal. Chem. 2016, 779, 4754.

(43) Guo, W.; Zhang, A.; Zhang, X.; Huang, C.; Yang, D.; Jia, N. Anal. Bioanal. Chem. 2016, 408, 7173-7180.

(44) Wang, H.; Pu, G.; Devaramani, S.; Wang, Y.; Yang, Z.; Li, L.; Ma, X.; Lu, X. Anal. Chem. 2018, 90, 4871-4877.

(45) Irkham; Watanabe, T.; Fiorani, A.; Valenti, G.; Paolucci, F.; Einaga, Y. J. Am. Chem. Soc. 2016, 138, 15636-15641.

(46) Reshetnyak, O. V.; Koval'chuk, E. P. Electrochim. Acta 1998, 43, 465-469.

(47) Reshetnyak, O. V.; Koval'chuk, E. P.; Skurski, P.; Rak, J.; Błażejowski, J. J. Lumin. 2003, 105, 27-34.

(48) Koval'chuk, E. P.; Reshetnyak, O. V.; Chernyak, A. O.; Kovalyshyn, Ya. S. Electrochim. Acta 1999, 44, 4079-4086.

(49) Arnold, J. S.; Browne, R. J.; Ogryzlo, E. A. Photochem. Photobiol. 1965, 4, 963-969.

(50) Gray, E. W.; Ogryzlo, E. A. Chem. Phys. Lett. 1969, 3, 658-660.

(51) Khan, A. U.; Kasha, M. J. Am. Chem. Soc. 1966, 88, 1574-1576.

(52) Khan, A. U.; Kasha, M. J. Am. Chem. Soc. 1970, 92, 3293-3300.

(53) Lewandowska-Andralojc, A.; Polyansky, D. E. J. Phys. Chem. A 2013, 117, 10311-10319.

(54) Liang, C.; Wang, Z.-S.; Bruell, C. J. Chemosphere 2007, 66, 106-113.

(55) House, D. A. Chem. Rev. 1962, 62, 185-203.

(56) Yamashita, K.; Yamazaki-Nishida, S.; Harima, Y.; Segawa, A. Anal. Chem. 1991, 63, 872-876.

(57) Gonzales-Velasco, J.; Rubinstein, I.; Crutchley, R. J.; Lever, A. B. P.; Bard, A. J. Inorg. Chem. 1983, 22, 822-825. 